\title{
The Effectiveness of Discovery Learning on Thematic Learning on the Understanding of the Concept Social Science in Class IV Elementary School Students
}

\author{
Riana Denik Ratiwi ${ }^{1}$, Erni Suharini ${ }^{2}$, Hamdan Tri Atmaja ${ }^{3}$ \\ ${ }^{1}$ Master Program Student of Primary Education, ${ }^{2,3}$ Master Program of Primary Education \\ Universitas Negeri Semarang, Semarang City, Indonesia \\ Corresponding Author: Riana Denik Ratiwi
}

\begin{abstract}
This research was descriptively to determine the effectiveness of Discovery Learning and Numbered Head Together on understanding the thematic learning concepts of Social Science content in fourth grade students of SD Sedabin Ahmad Yani, Kemusu District. The type of research used in this study was Quasi Experiment. The populations of this study were all fourth-grade students of SD Sedabin Ahmad Yani, Kemusu District with a total of 116 students, while the sample was 28 students. Data collection techniques used documentation and test techniques. Instrument test used a test which includes a test of the validity of the items with biserial correlation; the results obtained are 25 valid items and 5 invalid items. Reliability using the KR-20. The data analysis technique used was the distribution normality test, the homogeneity of variance test, and the Paired Sample T-Test.

The results of the descriptive study showed that the trend of understanding concepts in the experimental class using Discovery Learning obtained an average score of 21.142 and included in the very high category, while the control class using Numbered Head Together obtained an average score of 18.357 and also included in the high category. But the average score of Discovery Learning was higher than Numbered Head Together. So, it can be concluded that the understanding of the thematic learning concepts of Social Science content in the experimental class was higher than the control class. Based on the results of hypothesis
\end{abstract}

testing using the t-test, the result $=3.446,0.002$, it can be concluded that $<0.05$, there was a very significant difference between Discovery Learning and Numbered Head Together on understanding the thematic learning concepts of fourth grade students at SD Sedabin Ahmad Yani, Kemusu District.

Keywords: Concept Understanding Social Science, Discovery Learning

\section{INTRODUCTION}

Education is a planned activity in realizing learning activities and learning processes in which students are active in developing their abilities and potentials such as knowledge, personality, intelligence, skills, and culture that are needed in society, nation and state. According to Sari (2018), education is basically an effort to provide certain knowledge, insight, skills, experience and expertise to individuals to develop human talents and personalities. $\mathrm{Ki}$ Hajar Dewantara (2013) explained that "Education is guiding all the natural forces that exist in children, so that they as humans and as members of society can achieve the highest safety and happiness". According to $\mathrm{Ki}$ Hajar Dewantara, the tri-center of education is centered on three aspects of the educational environment, including the community environment, family environment, and school environment. Where these three aspects are interrelated in 
education. This is reinforced by Law No. 20 of 2003 concerning the education system, which is a conscious effort to create a learning atmosphere so that students actively develop their potential to have religious spiritual strength, self-control, personality, intelligence, noble character, and the skills they need. society, nation and state.

One of the components in education is the curriculum. The curriculum is a component that makes guidelines in the process of teaching and learning activities in educational units. The curriculum develops between theory and practice. One of the curriculums implemented in Indonesia is the 2013 curriculum. According to Yuliani (2014) explained that the 2013 curriculum is thematically integrative, namely the teaching and learning process based on themes and combines several lessons into one, namely Indonesian language, science, social studies, civic education, and SBdP subjects. The subject of this research is social studies subjects. In social studies learning at the elementary school level, the scope is different from social studies in general, at the elementary school level the scope is still relatively narrow, namely in social studies learning at the elementary school level, humans are studied in all aspects of life and their interactions in community life.

Rini Kristiantari (2015) added that the 2013 curriculum aims to guide and encourage students to be active in learning by using a scientific approach, namely observing, asking questions, seeking information, associating, and communicating what students get in everyday life in society. One of the thematic learnings that study about people's lives is social science. Rahmat et al., (2018) explained that Social Sciences (IPS) is a subject that is used to understand the concept of understanding the environment, social events, social interaction, economy and everything related to social issues. According to Hutama (2016) stated that social science is one of the compulsory subjects in elementary schools with that one of the duties of an educator himself is expected to be able to implement the implementation of social values well in the implementation process in the classroom.

Based on observations made by researchers on fourth grade students at SD Negeri Se-Dabin Ahmad Yani Kemusu Boyolali which was carried out for four days on, 16, 17, 18, 19 September 2020, the following obstacles were obtained: first, it was seen during learning thematic content in which there is Social Science (IPS) content, there were still many students who pay less attention to the teacher in delivering the material, there were students who had chat, went in and out of class for reasons of permission to go to the toilet, were busy playing alone, and lack concentration in participating in learning. Students have not been able to work on the practice questions given by the teacher optimally.

Second, it is known that the learning process was centered on the teacher (teacher center). Students were still not active in learning activities because during learning the teacher gives a lot of lectures about the material. So that the activities carried out by students usually only listen and take notes, students rarely asked questions or expressed opinions.

Third, there were students who still consider social studies subjects as subjects that read and memorize a lot. Fourth, the value and understanding of social studies concepts were still low, this can be seen from the results of the Middle Semester Assessment of students with an odd semester PTS average for Class IV SD Negeri Se-Dabin Ahmad Yani Kemusu Boyolali with the rules of Minimum Completeness Criteria (KKM) 70,00 there are still many students who have not received an average score according to the $\mathrm{KKM}$, and scored below the KKM standard.

Based on these observations, it can be concluded that the learning process at SD Negeri Se-Dabin Ahmad Yani Kemusu Boyolali needs an evaluation of understanding the concept of Social 
Sciences (IPS) for students. Thematic Learning on the Understanding of Social Sciences Concepts for Class IV Elementary School Students "This study aimed to overcome problems and improve understanding of Social Science concepts.

Efforts that can be made to overcome the problems above were the need to use innovative, fun learning models that were in accordance with the characteristics of students, so that students were able to participate actively, creatively, in the material being taught. The learning model that can be used in understanding the concept of Social Sciences (IPS) is to use Discovery learning and the Numbered Head Together (NHT) model.

Discovery learning is a learning process that involves students to organize, develop knowledge and skills for problem solving. Nursyamsi. et al (2016) stated that Numbered Head Together is "...The students are divided into small groups and directed to study the learning material that has been assigned". Discovery learning and Numbered Head Together models so that they can make social studies learning models fun and can increase understanding of concepts.

\section{LITERATURE REVIEW}

Based on review of research on Discovery Learning as a learning model to determine the extent to which students' ability levels in understanding social studies concepts were. According to Constructivism Learning Theory according to Dewey (1997) a behavioristic school emphasized the concept of Discovery Learning. With "Learning by doing" with Dewey's analysis, namely "the complete art of reflective" because learning by making an outline from confusing things to solving (Johnson, S. \& Blanchaerd, 1998).

According to Bruner, learning theory is learning in the cognitive development of students through three stages and is determined by looking at the natural and social conditions around students. (1) the enactive stage where students carry out activities in understanding the surrounding environment; (2) the iconic stage, there is the stage where students learn to teach by looking at pictures; (3) the symbolic stage, which is the stage where students argue that they are influenced by language and logic.

The Discovery Learning model is a learning theory that defines it as a teaching and learning process in the presentation of learning not in finished form, but students can find their own. As Bruner argued, that "Discovery Learning can be defined as the learning that takes place when the student is not presented with subject matter in the final form, but rather is required to organize it himself" (Lefancois in Emetebun, 1986: 103) in the 2013 Curriculum Implementation Teacher Training module. Bruner's opinion was the opinion of Piaget which stated that students in the teaching and learning process must play an active role where the teacher is only a facilitator.

According to Jerome Bruner, one of the cognitive instructional learning models is known as Discovery Learning in his theory where the teaching and learning process is by actively seeking knowledge and then seeking problem solving from the students themselves so as to produce meaningful knowledge (Trianto, 2007).

From the opinion above, it can be concluded that discovery learning is a teaching and learning process by finding problem solving, actively seeking knowledge from the students themselves so as to produce meaningful knowledge.

\section{MATERIALS \& METHODS}

This research was conducted at SD Negeri SeDabin Ahmad Yani Kemusu. The research used quantitative research methods with "Quasi Experimental research design with Pretest and Posttest Group Design. The object of this research was a test to measure the understanding of social science concepts for grade IV elementary school. The procedures for the stages in this research were as follows: 


\section{Technical Data Collection}

In data collection techniques to obtain more precise data used an instrument in the form of documentation and tests will be described by the researchers as follows:

\section{a. Test}

The test is an activity carried out by researchers to measure skills, knowledge, intelligence, as well as the ability or talent of something with established rules (Suharsimi, 2010). In this case, the researcher used a multiple-choice test with 4 answer choices, namely A, B, C, D to obtain data on understanding social science concepts for each group that was taught with a different learning model but the material was the same for fourth grade students at SD Negeri Sejahtera. Dabin Ahmad Yani Kemusu Boyolali.

\section{b. Documentation}

Documentation or archives are some direct data obtained from a place of research including relevant books, photos, and existing regulations (Sugiyono, 2014). Researchers looked up written data such as photos, names and lists of social studies scores for fourth grade students at SD Negeri Se-Dabin Ahmad Yani Kemusu Boyolali.

\section{Data Collection Instruments}

Test instrument to measure the effectiveness of Discovery Learning to improve understanding of social studies concepts for elementary school students. The test questions used as research instruments are in the form of multiple choice.

\section{a. Validity}

According to Suharsimi (2010), validity is an activity of measuring data that shows the level of validity in an instrument. The instrument will be said to be valid if it has high validity and vice versa the instrument is said to be invalid if it has low validity. An item said to be valid if it is able to measure what was desired. An item is said to be valid if it has the greatest support for the total score or it can be interpreted that the item is said to have high validity if the score on the item has parallels with the total score. Determination of the validity of the multiple-choice items the researcher uses the Biserial Correlation formula. The validity test was carried out a separate test, that was tested the instrument in other schools that were not used as the research sample.

\section{Item Validity}

Determined of the validity of multiple-choice items, the researcher used the Biserial Correlation formula as follows:

$\mathrm{Y}_{\mathrm{pbi}}=\frac{M_{p}-M_{t}}{S_{t}} \sqrt{\frac{p}{q}}$

(Suharsimi, 2017)

Notes:

Ypbi $=$ Biserial Correlation Coefficient

$\mathrm{Mp}=$ the average score of the subjects who answered correctly for the item sought for correlation with the test

$\mathrm{Mt}=$ Mean of total score (average score of all test takers)

$\mathrm{St}=$ Standard deviation of total score

$\mathrm{p}=$ Proportion of students who answered correctly

The test instrument in the form of multiple-choice questions has been tested and analyzed using the Ypbi biserial correlation formula manually with the help of Ms. Excel. Items were said to be valid if r-pbis is greater than r-table. Meanwhile, if the r-pbis is smaller than the r-table, the item was said to be invalid/invalid, the results of the instrument trial of 30 multiplechoice items presented on the material of various economic activities, the questions were categorized as invalid as many as 5 items, namely number 5, 18, 21, 27, and 25 questions were categorized as valid, namely numbers $1,2,3,4,6,7,8,9,10,11,12,13$, $14,15,16,17,19,20,22,23,24,25,26$, 28 , and 29 .

\section{Validation of Learning Tools}

Validation was also carried out in terms of the design of research instruments including test questions, validation of learning tools carried out including: Syllabus, RPP, LKPD. The results of the 
validation of research instruments and learning tools obtained an average of 4,23. It can be concluded that the instrument is valid and can be used with the advice of the validator. Validation of learning tools by calculating the tabulation of all data obtained from the validator for each component and assessment item available in the assessment instrument can be seen in table.

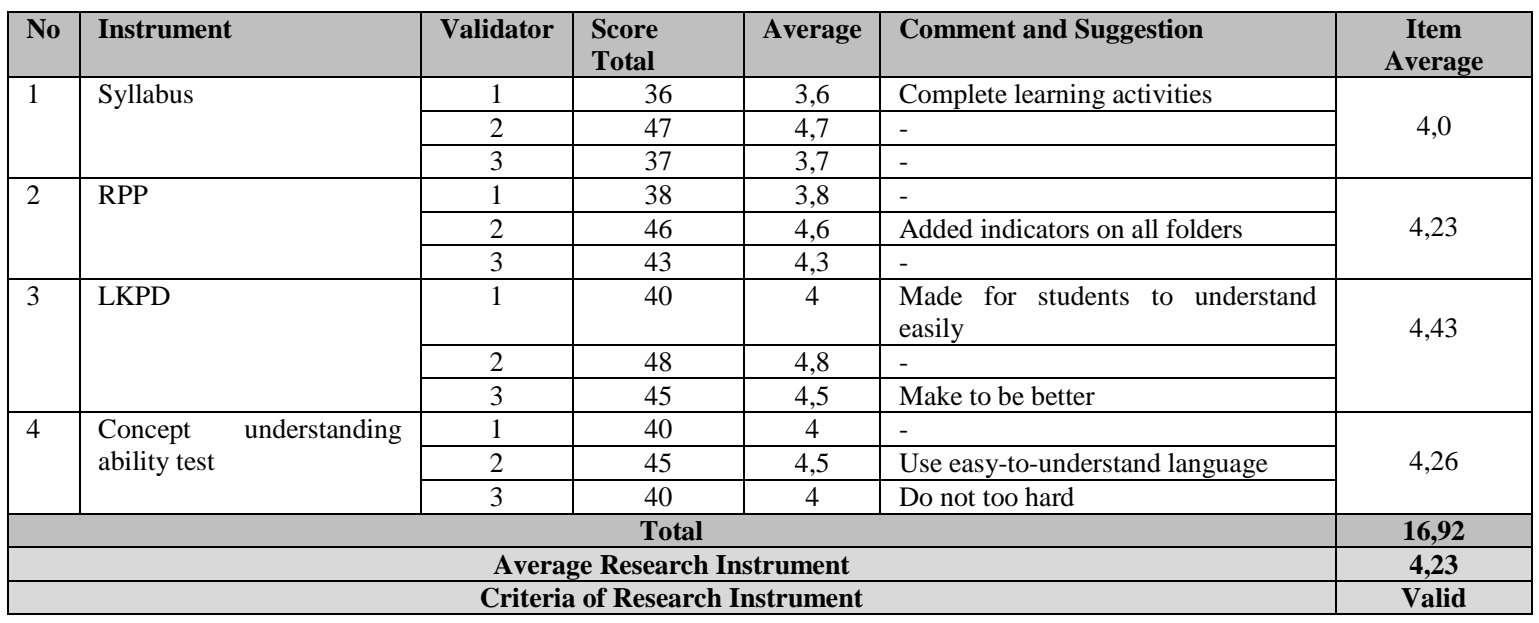

Find the average validator score used the formula:

$\mathrm{X}$ Validator Score $=$ Total Score Total of Indicator

Find the average score of tools I using the formula:

Tool score

$\mathrm{i}=\Sigma^{3} \mathrm{~m}-1$ Average of validator score

\section{Notes:}

$\mathrm{i}=1,2,3,4, \ldots$ (obtained instruments)

$\mathrm{m}=$ Validator $(\mathrm{m}=1,2,3)$

$\mathrm{n}=$ number of validator

The tool criteria were said to be valid for use in research if the results from the validator can be said to be good or very good. The following results of the criteria for the validity of the learning tools used in the study can be converted in table 2.2

\section{Learning Tools Validation Criteria}

\begin{tabular}{|c|c|}
\hline \multicolumn{1}{|c|}{ Score } & Criteria \\
\hline $4,2<<\bar{X} \bar{X}_{\leq 5,0}$ & Very Valid \\
\hline $3,4<\bar{X} \bar{X}_{\leq 4,2}$ & Valid \\
\hline $2,6<\bar{X} \bar{X}_{\leq} 3,4$ & Valid Enough \\
\hline $1,8<\bar{X} \bar{X}_{\leq 2,6}$ & Invalid \\
\hline $\bar{X} \bar{X} \leq 1,8$ & Very Invalid \\
\hline
\end{tabular}

Notes:

$\bar{x}:$ Average total score

Based on the results of the validation of the research instrument carried out, it was obtained an average of 4.23 and it can be concluded that both obtained valid criteria.

\section{b. Reliability Test}

According to Suharsimi (2010), reliability is a statement that the instrument is good and can be trusted to be used as a data collection tool. For testing the reliability of the instrument in the form of multiple choice which in this instrument will produce a dichotomy score of 1 and 0 , the researcher uses the K.R 20 (Kunder Richardson) formula as follows:

$$
\frac{\mathrm{k}}{(\mathrm{k}-1)}\left\{\frac{s_{t^{2}-\Sigma p_{i} q_{i}}}{s_{t^{2}}}\right\}
$$

\section{Notes:}

$\mathrm{k}=$ number of items in the instrument $\mathrm{p}_{\mathrm{i}}=$ the proportion of the number of subjects who answered on item 1

$\mathrm{q}_{\mathrm{i}}=1-\mathrm{p}_{\mathrm{i}}$

$\mathrm{S}_{\mathrm{t}}^{2}=$ variance total

The criteria for the classification of the reliability of the items can be seen in the following table.

\section{Reliability Criteria}

\begin{tabular}{|l|l|l|}
\hline No & \multicolumn{1}{|c|}{ Range } & \multicolumn{1}{|c|}{ Remark } \\
\hline 1 & $0,800 \leq \mathrm{r} \leq 1,00$ & Very High \\
\hline 2 & $0,600 \leq \mathrm{r}<0,800$ & High \\
\hline 3 & $0,400 \leq \mathrm{r}<0,600$ & Adequate \\
\hline 4 & $0,200 \leq \mathrm{r}<0,400$ & Low \\
\hline 5 & $0,00 \leq \mathrm{r}<0,200$ & Very Low \\
\hline
\end{tabular}


The results of the reliability test of students' basic social science concepts (IPS) variables using the K-R 20 formula. From the analysis results obtained rcount $=1.048$ meant that the test instrument was included in the category between 0.800 r 1.00 and has high reliability.

\section{Technical Data Analysis}

Data analysis is an activity process after data from respondents or data sources have been collected (Sugiyono, 2017). The testing in this study has three parts, namely normality test, homogeneity test and paired sample t-test, as follows:

\section{a. Distribution Normality Test}

The normality test was conducted by researchers to test whether the results of the pre-test and post-test were normal. The normality test of the data was carried out before the paired sample t-test. Normality test aims to determine the research data that has been collected is normally distributed or not. The normality test is carried out by calculating 2 (chi squared) based on the following formula (Suharsimi, 2017):

Notes:

$$
\left.x 2=\sum \underline{(\mathrm{f}}_{\underline{\mathrm{f}}-\mathrm{f}_{\mathrm{h}}}\right)^{2}
$$

$\mathrm{x}^{2}=$ chi square value

fo $=$ test frequency of the sample

$\mathrm{fh}=$ expected frequency of sample

The results of the normality test can be interpreted if the value $\chi 2_{\text {count }}$ smaller than $\chi 2_{\text {table, }}$ then it meant that the data is normally distributed. If the value $\chi 2_{\text {count }}$ bigger than $\chi 2_{\text {table }}$ it meant data is abnormal

\section{b. Homogeneity Test}

The homogeneity test aims to test the extent to which the variables in this study are homogeneous or not. The formula used is the F test. According to Sugiyono, (2011) to determine the effect between the two variables is homogeneous or not homogeneous.

$$
\mathrm{F}=\frac{\text { Varian }- \text { besar }}{\text { Varian }- \text { kecil }}
$$

\section{c. T-test}

This study used the Nonequivalent control-group design. In this study, observations were made before and after the experiment. Observations made before the experiment are called pre-test and observations made after the experiment are called post-test. To find out between the results of the pre-test and post-test. there was an impact or not, then the researcher uses the Paried Sample T-Test formula as follows:

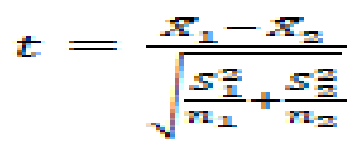

\section{Keterangan :}

$\bar{X}_{1}=$ rata-rata prestasi kelas eksperimen

$\bar{X}_{2}=$ rata-rata prestasi kelas kontrol

$n_{1}=$ besarnya sampel kelas eksperimen

$n_{2}=$ besarnya sampel kelas kontrol

$S_{1}^{2}=$ simpangan baku kelas eksperimen

$S_{2}^{2}=$ simpangan baku kelas control

$$
t=\frac{x_{1}-x_{2}}{\sqrt{\frac{s_{1}^{2}}{n_{1}}+\frac{s_{2}^{2}}{n_{2}}}}
$$

Notes:

$\bar{X}_{1} \bar{X}_{1}=$ the average achievement of the experimental class

$\bar{X}_{2} \bar{X}_{2}=$ the average achievement of the control class

$n_{1} n_{1}=$ the size sample of the experimental class

$n_{2} n_{2}=$ the size sample of the control class $S_{1}^{2} S_{1}^{2}=$ standard deviation of the experimental class

$S_{2}^{2} S_{2}^{2}=$ standard deviation of the control class

\section{RESULT \& DISCUSSION}

\section{Data Description}

The description of the results of the research on understanding the social studies concept was explained as follows. The test results of the control class and the experimental class were then analyzed for validity, level of difficulty, different 
potency, and reliability and continued with the analysis of trends and differences in learning outcomes. After being analyzed using item analysis, 25 items were used. Each item with the correct answer is given a score of 1 and the item with an incorrect answer is given a score of 0 , so the provisions of the ideal maximum score of $25 \times 1=25$ and the ideal minimum score are $25 \times 0=0$. Based on the ideal maximum score and ideal minimum score obtained the mean and standard deviation are as follows.
$\mathrm{M}$ ideal $=1 / 2$ (Maximum ideal score + minimum ideal score)

$$
\begin{aligned}
& =1 / 2(25+0) \\
& =1 / 2(25) \\
& =12,5
\end{aligned}
$$

SD ideal $=0,167$ (Maximum ideal score minimum ideal score)

$$
\begin{aligned}
& =0,167 \times(25-0) \\
& =0,167 \times 25 \\
& =4,17
\end{aligned}
$$

\begin{tabular}{|c|c|c|}
\hline Formula Interval & Score Range & Criteria \\
\hline$\overline{\mathrm{X}}>(\mathrm{Mi}+1,5 \mathrm{SDi})$ & $18,75<\bar{X}_{\leq 25,00}$ & Very High \\
\hline$(\mathrm{Mi}+0,5 \mathrm{Sdi}) \leq \overline{\mathrm{X}}<(\mathrm{Mi}+1,5 \mathrm{xSDi})$ & $14,58<\bar{X}_{\leq 18,75}$ & High \\
\hline$(\mathrm{Mi}-0,5 \operatorname{Sdi}(\leq \overline{\mathrm{X}}<(\mathrm{Mi}+1,5 \mathrm{xSDi})$ & $10,42<\bar{X} \leq 14,58$ & Medium \\
\hline$(\mathrm{Mi}-1,5 \mathrm{xSDi}) \leq \overline{\mathrm{X}} \leq(\mathrm{Mi}-0,5 \mathrm{Sdi})$ & $6,25<\bar{X} \leq 10,42$ & Low \\
\hline$<($ Mi-1,5xSDi) below & $0<\overline{\mathrm{X}} \leq 6,25$ & Very Low \\
\hline
\end{tabular}

Based on the results of the ideal mean (Mi) and the ideal standard deviation (SBi), the criteria for a normal curve with a scale of five are compiled as follows.

\section{Trends in understanding the concept of social studies}

Based on table it can be explained the tendency of understanding social studies concepts for experimental and control class students as follows.

1) The tendency to understand social studies concepts whose learning used the discovery learning model

The tendency of understanding social studies concepts in the experimental class, whose learning used the discovery learning model, which was attended by 14 fourth grade elementary school students, obtained an average score of 21.142 and the standard deviation was 2.14322. The average value of 21.142 in the normal curve is in the very high category with an interval between $18.75<25.00$. Then, it can be explained that the tendency of understanding social studies concepts whose learning uses the discovery learning model is very high.

2) The tendency to understand social studies concepts using the Numbered Head Together (NHT) learning model
The tendency of understanding social studies concepts which learning used the Numbered Head Together (NHT) learning model which was followed by 14 fourth grade elementary school students, got an average score of 18.357 and a standard deviation of 2.13423 . The mean value of 18.357 in the normal curve is in the high category with an interval between 14.78 < 18.74. Further, the tendency of understanding social studies concepts using the Numbered Head Together (NHT) learning model was high.

\section{Test Requirements Analysis a. Normality Test}

This normality test was used by chisquare analysis $(\chi 2)$. If the results showed a normal distribution, the analysis can be continued. The results of the normality test of the data obtained include data on understanding the social science concept. Normality test using Chi Square calculation. The results of the normality test for 
Riana Denik Ratiwi et.al. The effectiveness of Discovery Learning on thematic learning on the understanding of the concept Social Science in Class IV elementary school students

understanding the social science concept data can be seen in table.

Summary of Normality Test Results Understanding of Social Sciences concept

\begin{tabular}{|l|c|c|c|c|c|}
\hline Group & $\mathbf{D k}$ & $\mathbf{X}^{2}$ count & $\mathbf{X}^{2}$ table & $\boldsymbol{p}$-value & Remark \\
\hline Experiment & 7 & 5.429 & 14.067 & 0.608 & Normal \\
\hline Control & 6 & 9.600 & 12.592 & 0.143 & Normal \\
\hline
\end{tabular}

Based on table of the normality test results, the value of $\left(\chi^{2}\right)$ counts data on understanding social science concepts for students whose learning used the discovery learning model, the value of $\mathrm{X} 2$ count = $5.429<\mathrm{X} 2$ table $(14.067)$ with $\mathrm{p}$ value $=$ $0.608>0.05$ and the value of 2 counts data on understanding social science concepts students whose learning uses the Numbered Head Together (NHT) learning model, the value of $\mathrm{X} 2$ count $=9.600<\mathrm{X} 2$ table (12.592) with $\mathrm{p}$ value $=0.142>0.05$. Based on these results, it can be concluded that the two data were normally distributed.

\section{b. Homogeneity Test}

The homogeneity test aimed to test the extent to which the data has a homogeneous variance or not. In this study, the homogeneity test was calculated using the $\mathrm{F}$ test. The results of the data homogeneity test for understanding the social science concept and communication skills can be seen in table.
Summary of Homogeneity Test Understanding the Social Science concept

\begin{tabular}{|l|c|c|c|c|c|}
\hline \multicolumn{1}{|c|}{ Group } & Variance & $\begin{array}{c}\text { F } \\
\text { count }\end{array}$ & $\begin{array}{c}\text { F } \\
\text { table }\end{array}$ & $\begin{array}{c}\text { p- } \\
\text { value }\end{array}$ & Remark \\
\hline Experiment & 4.593 & 0.082 & 4.225 & 0.777 & Humogen \\
\hline Control & 4.555 & & & & \\
\hline
\end{tabular}

Based on table the calculation results of SPSS for windows statistical analysis between students' understanding of social studies concepts using the discovery learning model and those whose learning used the Numbered Head Together (NHT) learning model has a value of Fcount $=$ $0.082<\mathrm{F}$ table $(4.225)$ with $\mathrm{p}$ value $=0.777$ $>00.05$, so that the two data were homogeneous.

\section{Data Analysis Test Results}

The hypothesis was a temporary answer to the problem that has been formulated. Hypothesis testing can be done if the normality and homogeneity of the research data have been met. In this study, to test the hypothesis in this study using the t-test (t-test). The results of hypothesis testing between understanding the social science concept can be seen in table.

Summary of the results of the t-test (t-test) Understanding the concept of Social Sciences

\begin{tabular}{|c|c|c|c|c|c|c|}
\hline Group & $\mathbf{N}$ & Average & SB & $\mathbf{t}_{\text {count }}$ & p-value & Remark \\
\hline Experiment & 14 & 21.142 & 2.14 & 3.446 & 0.002 & Very significant \\
\hline Control & 14 & 18.357 & 2.13 & & & \\
\hline
\end{tabular}

Based on the analysis table above, the value of tcount $=3,446$ with $p$ value $=$ $0.002<0.05$. Further, there was a very significant difference in social studies learning outcomes taught using the discovery learning model and the Numbered Head Together (NHT) learning model.

By looking at the average score of understanding social studies concepts in the experimental class of 21,142 and the control class of 18,357 , the understanding of social studies concepts using the discovery learning model is higher than the understanding of social studies in the fourthgrade elementary school students with the Numbered Head Together (NHT) learning model. This meant that the discovery learning model has more influence on understanding the social studies concept than the Numbered Head Together (NHT) learning model.

\section{CONCLUSION}

1. The tendency of understanding social studies concepts for fourth grade elementary school students whose learning uses discovery learning was very high with an average value of 21.14 in the interval between $18.75<<25$.

2. The tendency of understanding social studies concepts for fourth grade elementary school students whose 
learning used Numbered Head Together (NHT) was high with an average value of 18.36 in the interval between 14.78 $<18.75$.

3. The results showed that there was a significant difference in social studies learning outcomes taught using discovery learning with Numbered Head Together (NHT) with tcount $=3,446$ with $\mathrm{p}$ value $=0.002<0.05$. Further, looking at the mean score of understanding social studies concepts in the experimental class 21.14 and the control class 18.36 , the understanding of social studies concepts using discovery learning was higher than the level of understanding of students using Numbered Head Together (NHT). Discovery learning has more influence on understanding the concept of Social Sciences than Numbered Head Together (NHT).

\section{Acknowledgement: None}

\section{Conflict of Interest: None}

\section{Source of Funding: None}

\section{REFERENCES}

1. Hutama, F. S. (2016). Pengembangan Bahan Ajar Ips Berbasis Nilai Budaya Using Untuk Siswa Sekolah Dasar. JPI (Jurnal Pendidikan Indonesia), 5(2), 113. https://doi.org/10.23887/jpiundiksha.v5i2.8359

2. Johnson, S. \& Blanchaerd, K. (1998). Who movedmy cheese?: An amazing way to deal with change in your work and in your life. New York (Penguin Pu).

3. Ki Hajar Dewantara. (2013). Pemikiran,Konsep, Konsepsi, Keteladanan, Sikap Merdeka Pendidikan.

4. Nursyamsi, S. Y., \& Corebima, A. D. (2016). The Effect of Numbered Heads Together (NHT) Learning Strategy on The Retention of Senior High School Students in
Muara Badak, East Kalimantan, Indonesia. European Journal of Education Studies, 2(5), 47-58. www.oapub.org/edu.

5. Rahmat, A. S., Sumantri, M. S., \& Deasyanti, D. (2018). Peningkatan Hasil Belajar IPS Materi SDA dan Pemanfaatannya melalui Model Pembelajaran Inquiry Berbantuan Media Games Book di Kelas IV Sekolah Dasar. Indonesian Journal of Primary Education, 2(1), https://doi.org/10.17509/ijpe.v2i1.11646

6. Rini Kristiantari, M. (2015). Analisis Kesiapan Guru Sekolah Dasar dalam Mengimplementasikan Pembelajaran Tematik Integratif Menyongsong Kurikulum 2013. JPI (Jurnal Pendidikan Indonesia), 3(2), 460-470. https://doi.org/10.23887/jpiundiksha.v3i2.4462

7. Sugiyono. (2011). Statistika untuk Penelitian (CV ALFABET).

8. Sugiyono. (2013). Statistika untuk Penelitian (CV ALFABET).

9. Sugiyono. (2014). Metode Penelitian Bisnis (Pendekatan Kuantitatif, Kualitatif dan $R \& D)$ (CV ALFABET).

10. Sugiyono. (2017). Metode Penelitian Bisnis (Pendekatan Kuantitatif, Kualitatif dan $R \& D)$ (CV ALFABET).

11. Suharsimi, A. (2010). Dasar-dasar Evaluasi Pendidikan (Bumi Aksar).

12. Suharsimi, A. (2017). Prosedur Penelitian (Suatu Pendekatan Praktik) (PT RINEKA).

13. Trianto. (2007). Model-model Pembelajaran Inovatif Berorientasi Konstruktivisme (Prestasi P).

14. Yuliani. (2014). Penerapan Kurikulum 2013 selalu Menuai Masalah.

How to cite this article: Riana Denik Ratiwi, Erni Suharini, Hamdan Tri Atmaja. The effectiveness of Discovery Learning on thematic learning on the understanding of the concept Social Science in Class IV elementary school students. International Journal of Research and Review. 2021; 8(10): 117-125. DOI: https://doi. org/10.52403/ijrr.20211016 